University of Zurich

Department of Economics

Working Paper Series

ISSN 1664-7041 (print)

ISSN1664-705X(online)

Working Paper No. 22

\title{
The Impact of Immigration on the Wage Distribution in Switzerland
}

Sandro Favre

August 2011 


\title{
The Impact of Immigration on the Wage Distribution in Switzerland
}

\author{
Sandro Favre, University of Zurich*
}

August 10, 2011

Recent immigrants in Switzerland are overrepresented at the top of the wage distribution in high and at the bottom in low skill occupations. Basic economic theory thus suggests that immigration has led to a compression of the wage distribution in the former group and to an expansion in the latter. The data confirm this proposition for high skill occupations, but reveal effects close to zero for low skill occupations. While the estimated wage effects are of considerable magnitude at the tails of the wage distribution in high skill occupations, the effects on overall inequality are shown to be negligible.

JEL-Classification: F22, J31, J61

Keywords: Immigration, Wage Distribution, Occupation Groups, Inequality

*I thank Beatrice Brunner, Christian Dustmann, Christian Hepenstrick, Andreas Kuhn, Philippe Ruh, Andreas Steinhauer, and Josef Zweimüller as well as seminar participants in Zurich and participants at the 2011 Norface Migration Network Conference on "Migration: Economic Change, Social Challenge" for helpful comments. Financial support by the Austrian Science Fund is gratefully acknowledged ("The Austrian Center for Labor Economics and the Analysis of the Welfare State"). Contact: Sandro Favre, Department of Economics, University of Zurich, Mühlebachstrasse 86, CH-8008 Zurich; sandro.favre@econ.uzh.ch 


\section{Introduction}

The past fifteen years have seen a remarkable change in the education levels of recent immigrants in Switzerland (Figure 1). Due to a change in immigration policy (see Section 2 ) the share of college graduates among workers who recently immigrated has nearly tripled, even surpassing the respective share of natives. At the same time, however, the share of recent immigrants with no more than mandatory education, while continuously decreasing, is still higher than the respective share of natives. Thus, recent immigrants in Switzerland are overrepresented at both the bottom and the top of the education distribution. More importantly still, as I will show below, this is also reflected in the fact that immigrants are overrepresented at both tails of the wage distribution - that is, they compete with both the bottom and top tier of native workers. In this paper, I assess how this bi-polar immigration has affected the wages of natives. I go beyond traditional analyses of the wage effects of immigration firstly by studying the effects along the distribution of wages instead of only the mean wage effects, secondly by providing estimates for the effects on overall inequality, and thirdly by contrasting the overall effects with the effects on those groups of native workers who are most intensely affected by immigration.

\section{Figure 1 about here}

Every study that examines the causal effects of immigration on the wages of natives must find a plausible approximation for the counterfactual. Typically, this is done by dividing the country of interest into a number of regional units (e.g. Grossman, 1982, Card, 1990; Altonji and Card, 1991; LaLonde and Topel, 1991; Hunt, 1992, Card, 2001, Hanson and Slaughter, 2002, Lewis, 2004) or education-experience groups (e.g. Borjas et al., 1996, 1997, Borjas, 2003. Ottaviano and Peri 2006). A common feature of all earlier studies is that they then correlate changes in immigrant shares and mean wages across these crosssectional cells 1 In a recent essay, Dustmann et al. (2008b) tread a new path in the research of the wage effects of immigration. While following a spatial correlations approach, they assess the effects of immigration along the wage distribution rather than on mean wages. This procedure is motivated by the notion that immigration affects workers with different skill (and thus pay) levels very

\footnotetext{
${ }^{1}$ This lumping together of the existing literature into two very broad groups does not do justice to the myriad of innovations introduced by the different authors and the controversial yet prolific debate about the wage effects of immigration they represent. However, it serves my limited purpose of contrasting my own research with previous studies. I do not have a bad conscience in doing so because there are a number of excellent surveys on this literature (e.g. Dustmann et al. 2008a, Okkerse 2008) and even a readable newspaper article summarizing the core of the debate (Lowenstein, 2006).
} 
differently, and that a focus on mean effects hence is not very insightful ${ }^{2}$ They show that recent immigrants in the UK are overrepresented at the bottom of the native wage distribution and underrepresented at the top, and that immigration has consequently decreased wages at the bottom and increased wages at the top of the wage distribution, while barely affecting the mean.

In my essay, I follow the lead of Dustmann et al. (2008b). However, I divide the labor force into a number of occupation-experience groups rather than regions since the spatial approach has been criticized by some authors and their critique is particularly relevant in the case of small-scale Switzerland ${ }^{3}$ Furthermore, while Dustmann et al. confine themselves to revealing the wage effects at different parts of the wage distribution, I follow through by estimating the effect of immigration on overall inequality. I then put this overall effect into perspective by comparing it to the magnitude of the effects felt by subgroups of the labor force - namely those whom immigration most intensely affects.

The case of Switzerland is interesting for two reasons. Firstly, as stated above, Switzerland attracts not only very poorly educated immigrants, as do most developed countries, but also a large number of exceptionally well educated ones. While it is true that some other countries attract highly educated immigrants as well, these usually experience a significant downgrade upon arrival - that is, they end up competing with natives with a low education level ${ }_{4}^{4} \mathrm{In}$ contrast, as I will show below, many of the highly educated immigrants end up in highly paid positions in Switzerland and thus compete with the upper tier of native workers. This rounds off the previous debate about the wage effects of immigration, which focuses on the effects on low-wage natives; in particular, it complements the analysis by Dustmann et al. (2008b). Secondly, the analysis of Switzerland is interesting for "domestic" reasons. The recent change in immigration policy (detailed in Section 2), which saw an unprecedented opening towards immigration from EU and EFTA countries, has given rise to a vigorous debate about - among others - the wage effects of immigration. The prominence of this issue in the political debate contrasts with its scarce econometric assessment. There is only one recent econometric study on the effects of immigration on wages in Switzerland by Gerfin and Kaiser (2010), who follow Borjas (2003)

\footnotetext{
${ }^{2}$ While it is true that previous studies have tried to take the heterogeneity of the effects of immigration on differently skilled natives into account, they have done so by pre-allocating immigrants and natives to education groups. However, Dustmann et al. show that such an approach is likely to be misspecified since the labor market values foreign education significantly less than domestic education (i.e., immigrants experience a "downgrade" upon arrival).

${ }^{3}$ The critics argue that the effects of immigration dissipate quickly across the whole country, which disguises the effect of immigration in the spatial correlations approach. This seems likely in as small a country as Switzerland. The extent to which this is the case in other countries is highly debated. Most notably, Card and DiNardo (2000) and Card (2001 2005) find no evidence for native outmigration. Prominent opposition arises from Borjas et al. (1997) and Borjas 2003 2006).

"This is in fact exactly the situation Dustmann et al. (2008b) describe for the UK.
} 
and estimate mean wage effects based on the elasticities of substitution between occupation-experience groups 5 Thus, my essay is also aimed at enriching up the political debate with econometric insights, adding to the analysis of Gerfin and Kaiser the focus on the wage distribution as sketched above.

The remainder of my essay is organized as follows. The next section discusses the institutional background and the most important recent trends in immigration to Switzerland. In Section 3 I present the empirical framework of my analysis. Section 4 provides a short discussion of data source and definitions. The main results of my analysis are presented in Section 5. I assess the extent of the wage effects of immigration on overall inequality in Switzerland as well as on subgroups of the labor force in Section 6. The final section concludes.

\section{Institutional Background}

In 1991, the Swiss Federal Council outlined the cornerstones of a new immigration policy: immigration from EU and EFTA countries should be gradually liberated from any constraints, immigration from developed countries outside the EU and EFTA - mainly the United States, Canada, and Australia - should be restricted to highly skilled workers, and immigration from other countries entirely stopped except for in a few exceptional cases ${ }^{6}$ This policy was then gradually implemented into the issuance of residency permits and perpetuated with the signing of the "Agreement on the free movement of persons" (FMP) between Switzerland and the EU, enacted in June 2002. While the FMP was originally concluded between Switzerland and the fifteen member states of the EU as of 1999 (EU-15), it was subsequently extended to the new member states. Immigration was initially limited by yearly quotas; these were gradually increased and finally abandoned (for the EU-15) in June 2007/7 Additionally, in order to prevent a deterioration of the labor conditions for low earners due to increased competition by immigrants, Swiss policymakers passed a package of supportive measures ["Flankierende Massnahmen"]. Within the frame of these measures, independent commissions monitor the adherence to collective labor agreements and to the customary labor conditions.

The reorganization of the Swiss immigration policy in the early 1990s led to a significant change in the composition of immigrant inflows. Immigration from EU and EFTA countries has dramatically increased both in relative and in

\footnotetext{
${ }^{5}$ As opposed to the scarce econometric literature, there are an ample number of descriptive analyses. The most notable of these studies are Avenir Suisse and Müller-Jentsch, eds (2008), a multi-faceted overview over the consequences of recent immigration by the think tank Avenir Suisse, and SECO (2010), the latest version of an annual report by the Swiss State Secretariat for Economic Affairs (SECO).

${ }^{6}$ Bundesblatt, Vol. 3, 1991, p. 291-303.

${ }^{7}$ See SECO 2010$)$ for the extent of the quotas as well as exhaustion rates.
} 
absolute terms. As already discussed, this shift in the origin of immigrants goes hand in hand with an increase in their educational levels (Figure11). As discussed below, this is also reflected in an increasing share of immigrants active in high skill jobs, which implies increased competition at the upper end of the wage distribution. All of these changes were of a gradual rather than a discontinuous nature since the revision of immigration policy was not designed as a sudden rupture, but as a continuous evolution.

\section{Estimation Strategy}

\subsection{Comparison of Occupation-Experience Groups}

The core of every study on the wage effects of immigration lies in finding a plausible approximation for the counterfactual (the wage changes that would have occurred in the absence of immigration), which is unobserved. Usually, this is achieved by dividing the labor force into a number of subgroups across which differences in immigration can be correlated with differences in wage changes. An approximation of this sort is associated with two potential problems. Firstly, if there are no barriers to a relocation of workers from one group to another, the effects of immigration to one group may be dispersed across the whole labor market. Secondly, if the allocation of immigrants to groups is not exogenous to labor market outcomes, the correlation between immigration and wage changes does not reflect the causal effect of immigration on wages.

Dustmann et al. (2008b), whose approach I adapt to the case of Switzerland, follow the mainstream of the immigration literature and approximate the counterfactual by comparing regional labor markets. In this setup, it is likely that the distribution of immigrants across cross-sectional cells is endogenous. In particular, most immigrants settle in regions where they have found or expect to find a good job, and the regional distribution of immigrants is thus highly correlated with both current and future labor market outcomes. This is widely accepted in the literature and partly accounted for by the use of IV approaches (e.g. Altonji and Card, 1991, Card, 2001) or the analysis of natural experiments (e.g. Card, 1990). A second problem arises from the inter-regional mobility of workers. If workers find that immigration deteriorates their labor market prospects in the current region of residence, they could move or commute to another region, and consequently, the effects of immigration would not remain localized to the region experiencing the inflow of immigrants. It is heavily disputed whether the workers' mobility is large enough to pose a problem 
for the spatial approach 8 However, one can make a strong argument that it indeed poses a problem in the case of small-scale Switzerland?

Since the spatial approach is thus inappropriate for an analysis of the Swiss labor market, I deviate from the procedure developed by Dustmann et al. and compare outcomes across occupation-experience groups (see Friedberg, 2001 for a similar approach) ${ }^{10}$ Since job applicants are usually required to dispose of a certain amount of working experience in the relevant field, workers are virtually immobile with respect to occupation-experience groups. Hence, a dispersion of the effects of an immigrant inflow across all cross-sectional cells is a minor issue in this approach. The problem of endogeneity, however, still exists. If domestic labor supply in an occupation group falls short of labor demand, wages tend to rise and employment prospects are bright, which attracts immigrants and encourages employers to search for workers abroad. Thus, immigrant density is positively correlated with labor market outcomes, and an OLS regression that seeks to find the causal effect of immigration on wages is thus subject to an upward bias - that is, it delivers too optimistic a picture of the effects of immigration. The OLS coefficients obtained in my analysis therefore have to be interpreted as upper bounds for the true effects of immigration. I address this issue with an IV approach that is outlined in Section 3.3

\subsection{Changes along the Distribution of Wages}

The theoretical motivation for my empirical approach is derived from the simple model outlined by Dustmann et al. (2008b) 11 Specifically, they model an economy that produces one output good using capital and a labor aggregate composed of a number of differential skill groups. If capital supply is perfectly elastic, an increase in immigrant density in this economy has no effect on wages if immigrants are distributed across skill groups in the same proportions as natives (because relative factor supply remains unaffected). If the distribution of immigrants across skill groups differs from that of natives, an increase in immi-

\footnotetext{
${ }^{8}$ Most notably, Card and DiNardo (2000) and Card (2001) find no evidence for native outmigration. Prominent opposition arises from Borjas (2003).

${ }^{9}$ An examination of transport travel times between the five largest cities in Switzerland is illustrative. From Zurich, the eastern-most of these cities, Basel and Berne are accessible by train within less than one hour, Lausanne in only slightly more than two hours, and Geneva in less than three hours.

${ }^{10}$ Specifically, I use the 23 occupation categories provided by the LSE (see table 1 and form three age groups (18-34, 35-49, and 50-65) as a proxy for experience. See Section 4 for more details. Some studies divide the labor force into skill groups in terms of education and experience (e.g. Borjas, 2003 Gerfin and Kaiser 2010) rather than regions or occupation groups, but this procedure has been criticized since education is a very rough measure for the relevant labor market skills. Immigrants and natives disposing of the same level of education may thus compete for very different jobs (see e.g. Dustmann et al., 2008b).

${ }^{11}$ Since this model is elaborated in detail in their paper, 1 am content with intuitively discussing its main implications.
} 
grant density increases the wages of those skill groups in which immigrants are underrepresented (because they become more scarce) and decreases the wages of those skill groups in which immigrants are overrepresented (because they become more abundant). In the case of imperfect capital supply, the effects are overall more negative but those skill groups in which immigrants are relatively more frequent still lose relatively more. This simple theoretical model hence provides a formalization of the notion that immigration deteriorates the labor market outcomes of "similar" natives and improves the outcomes of "dissimilar" natives.

In my empirical approach, the unit of observation (the "economy" in terms of the theoretical model) is an occupation-experience group. The skill distribution in this group is represented by the wage distribution. That is, if immigrant density in an occupation-experience group increases, I expect that wages will decrease at those parts of the wage distribution where immigrants are overrepresented and increase at those parts where immigrants are underrepresented. These changes are identified by comparing different occupationexperience groups ("economies") with different extents of immigration ${ }^{12}$

This reasoning suggests a two-stage procedure for the analysis. In the first step, which is of merely descriptive nature, I determine the position of immigrants in the resident wage distribution. This is needed to derive predictions as to which wage percentiles are adversely affected by immigration (the percentiles where immigrants are overrepresented) and which are favorably affected (the percentiles where immigrants are underrepresented). The second step comprises the regression analysis, which reveals how the wage percentiles are actually affected and thus tests the hypotheses derived in the first step ${ }^{13}$

For the regression equation of step two, the theoretical model outlined above implies a linear relationship between the log of wage percentiles in an occupationexperience group and immigrant density in the group. I therefore estimate the

\footnotetext{
${ }^{12}$ This is best illustrated with a specific example. Consider the occupation group of construction workers. Construction workers are very heterogeneous with respect to their skills, which is reflected in their wages. We find unqualified laborers performing basic tasks on the building site at the bottom of the wage distribution of construction workers, and specialized workers who lead and instruct the laborers at the top of the distribution. Suppose that immigrants in the construction sector are predominantly low skilled. If there is an inflow of foreign construction workers, this will increase competition for laborers on the one hand and increase demand for team leaders on the other. As a result, wages at the bottom of the wage distribution decrease while wages at the top increase. To be able to identify these wage effects, I compare the changes in the wage distribution of construction workers to those in the wage distribution of workers in other occupations (e.g. retail sale), which do not experience an immigrant inflow.

${ }^{13}$ The two steps of my analysis are technically unrelated: the first step is only used to obtain predictions on the outcome of the second step and does not affect the specification of the regression equations. Due to this unrelatedness and the specificity of the hypotheses tested in the second step, a confirmation of these hypotheses provides strong empirical evidence that the underlying framework accurately describes the economic mechanisms at work.
} 
model

$$
\log w_{p i t}=\alpha_{p i}+\beta_{p t}+\gamma_{p} m_{i t}+\delta_{p} X_{i t}+\epsilon_{p i t},
$$

where $w_{p i t}$ denotes the $p$ th wage percentile of residents in occupation-experience group $i$ in period $t, \alpha_{p i}$ denotes a group fixed effect, $\beta_{p t}$ denotes a time fixed effect, $m_{i t}$ denotes the share of immigrants in group $i$ at time $t$, and $X_{i t}$ is a vector of observable socioeconomic characteristics of group $i$ in period $t{ }^{14}$ To control for group-specific effects, I analyze a number of cross-sections observed at different points in time and calculate first differences ${ }^{15}$ Hence, the regression equation takes the form

$$
\begin{aligned}
\left(\log w_{p i t}-\log w_{p i t-1}\right)= & \left(\beta_{p t}-\beta_{p t-1}\right)+\gamma_{p}\left(m_{i t}-m_{i t-1}\right) \\
& +\delta_{p}\left(X_{i t}-X_{i t-1}\right)+\left(\epsilon_{p i t}-\epsilon_{p i t-1}\right) .
\end{aligned}
$$

The change in the time fixed effect captures the influence of the business cycle and the inclusion of the change in vector $X_{i}$ allows us to control for changes in the composition of the labor force in an occupation-experience group that affect wages.

I estimate equation (2) for every fifth wage percentile since I want to examine how a change in overall immigrant density affects each percentile. The parameters of interest in these regressions are the coefficients $\gamma_{p}$. The theoretical framework outlined above suggests a very specific pattern of these coefficients: they are predicted to be negative for those percentiles where immigrant density is above average and positive for those percentiles where immigrant density is below average.

The position of immigrants in the native wage distribution has to be similar in all units of observation in order for the regressions to yield meaningful coefficients. To see this, consider a simple example. If immigrants were overrepresented at the bottom of the wage distribution in one half of the occupation groups and at the top in the other half, we would expect the bottom percentiles to be adversely affected in the first half and favorably affected in the latter. The average effect - and thus the regression coefficient - would be close to zero and

\footnotetext{
${ }^{14}$ The wage percentiles are defined such that $p$ percent of the resident workers in group $i$ at time $t$ earn a wage below or equal to $w_{\text {pit }}$. The socioeconomic characteristics I control for are average age, ratio of workers with high to low education levels, ratio of medium to low education levels, share of earlier immigrants, and share of border commuters in an occupationexperience group. However, robustness checks show that the choice of controls is not critical for my results.

${ }^{15}$ Specifically, the data of the LSE, which are used for the regression analysis, are available for every other year from 1994 to 2008. In my baseline setup, I use all of these surveys - that is, I analyze changes over two-year-periods. As a robustness check, I calculate changes from 1994 to 2000 and from 2000 to 2008 , which reduces the number of cross-sections to two. See Section 4 for details on the data and Section 5.2 for details on the exact specification of the regressions.
} 
meaningless due to the heterogeneity in the effects. Section 5.1 shows that the position of immigrants in the native wage distribution fundamentally differs between high and low skill occupations but is roughly similar within each of these two categories. I am thus able to test my hypotheses by running the percentile regressions separately for low and high skill occupations.

In my analysis, I distinguish between two groups of residents, which may be differently affected by immigration: natives and earlier immigrants 16 Differences between natives and earlier immigrants may arise for two reasons. Firstly, differences in the skill composition between the two groups could imply a different location of immigrants in the two wage distributions and thus suggest differential effects of immigration on the distributions. Secondly, the substitutability between recent immigrants and these two groups might differ due to differences in unobserved characteristics.

\subsection{Dealing with Endogeneity}

The coefficients obtained in an OLS estimation of equation 2 suffer from an upward bias due to the endogeneity of the share of recent immigrants ${ }^{17}$ While the use of an IV approach along the lines of Card (2001) has become the state of the art in the spatial analysis of the effects of immigration, researchers who follow an occupation or skill group approach either only report OLS coefficients or employ the lag of the immigrant share as an IV without substantiating the validity of this procedure 18

The IV approaches used in spatial analyses are based on the finding by Bartel (1989) that newly arriving immigrants seek connection to a network of compatriots and thus tend to settle in regions where they find a large number of fellow countrymen. If the settlement pattern of earlier immigrants is uncorrelated with the subsequent development of local labor markets, this behavior leads to variation in immigrant density across regions which is exogenous to local labor market conditions and can thus be used to identify the causal effect of immigration on the wages of residents. Altonji and Card (1991) were the first to make use of this finding and employ the regional distribution of immigrants in a base year as an IV for changes in immigrant density. Card (2001) refined this procedure by distributing the immigrants arriving in a particular year across region-occupation groups according to the nationality-specific

\footnotetext{
${ }^{16}$ For a definition of these groups see Section 4

${ }^{17}$ Put formally, the change in immigration, $\left(m_{i t}-m_{i t-1}\right)$, is positively correlated with the error term, $\left(\epsilon_{\text {pit }}-\epsilon_{\text {pit-1 }}\right)$.

${ }^{18}$ To the best of my knowledge, the only exception to this is Friedberg (2001), who uses the occupation of immigrants in their home country as an IV for their occupation in the new country of residence. Her approach, however, hinges upon the unique circumstances of the natural experiment she assesses and can thus not generally be employed.
} 
settlement patterns in a base year. I argue that a very similar approach to address the endogeneity in the share of recent immigrants can be employed in an occupation-experience group analysis. Specifically, I distribute immigrants arriving in a particular year across occupation-experience groups according to the occupational distribution of foreigners in 199419

This IV for the change in the share of recent immigrants must meet three criteria: (i) it must be correlated with the change in the share of recent immigrants (the endogenous regressor); (ii) it must not have any direct effects on wage changes (the dependent variable); (iii) it must be exogenous, that is, uncorrelated with labor demand shocks affecting wages. The adherence to criterion (i) can both be established intuitively and tested empirically. As for intuition, a rich sociological and economic literature has stressed the importance of informal networks in job search 20 One strand of the literature on this topic has shown that ethnicity is an important characteristic determining these networks, and that the probability of a worker being hired by a firm thus increases in the share of workers from the same ethnic group already employed (e.g., Patel and Vella, 2007, Dustmann et al. 2010). Newly arriving immigrants are therefore likely to start pursuing a profession that a large number of earlier immigrants from the same source country pursue. Hence, the occupational distribution of the established immigrant population can be used to predict changes in the share of immigrants. This claim is thoroughly tested in the first stage regressions, the results of which are revealed in Section 5.3 .

The adherence to criteria (ii) and (iii) cannot be tested empirically, but must be substantiated solely on argumentative grounds. Criterion (ii) is likely to be met, since there is no obvious reason why the share of foreigners in an occupation as of 1994 should affect changes in the wage distribution in subsequent years. Fulfillment of criterion (iii) is more questionable. The distribution of immigrants in 1994 is correlated with contemporaneous labor market shocks, and if these persist over time, the IV is correlated with the error term. If the first stage is only weak, the resulting bias in the IV estimator may even exceed the bias in the OLS estimator. My IV results should thus be interpreted cautiously.

\footnotetext{
${ }^{19}$ Three remarks are in order. Firstly, one would prefer a base year that lies further in the past. However, the classification of occupations is specific to the LSE, and I therefore have to calculate the occupational distribution based on the earliest available wave of the LSE. Secondly and unfortunately, the LSE does not report the nationality of workers. Hence, instead of distributing immigrants across occupations according to the nationality-specific occupational distribution in 1994 I have to use the occupational distribution of all foreigners. And thirdly, since I run my regressions separately for high and for low skill occupations, I construct my instrumental variable separately for these two groups; that is, I distribute high (low) skill immigrants across high (low) skill occupations according to the occupational distribution of foreigners in high (low) skill occupations.

${ }^{20}$ For an encompassing overview see Ioannides and Datcher Loury (2004).
} 


\section{Data, Sample, and Definitions}

The data used for my core analysis stem from the Swiss Earnings Structure Survey (LSE), conducted by the Swiss Federal Statistical Office [Schweizerisches Bundesamt für Statistik, BFS], and cover all even years from 1994 to 2008 (which are all years the LSE is currently available for). Compared to the Swiss Labour Force Survey [Schweizerische Arbeitskräfteerhebung, SAKE], the main data source for most previous studies (e.g. Küng, 2005, Gerfin and Kaiser, 2010), the LSE features two advantages. Firstly, the sample size is much larger, which is particularly critical for the calculation of immigrant shares in a sample that is divided into a large number of cross-sectional cells. Secondly, the categorization of occupations is very appropriate for dividing the sample into cross-sectional cells, and a variable reporting the skill requirements for the tasks of each worker allows for an easy assessment of the skill dimension. I exclude workers below 18 or above 65 years of age as well as those employed in the public sector from the sample ${ }^{21}$

Natives, earlier immigrants, and recent immigrants. The basic aim of my analysis is to reveal how the inflow of workers from abroad affects the wages of Swiss natives and earlier immigrants. The LSE allows a rough identification of these three population groups based on citizenship and residency permit. The level of immigration is defined as the change in the labor force share of "recent immigrants", that is, foreign citizens with an annual residency permit (B permit) or a short term residency permit (L permit) ${ }^{22}$ Swiss citizens are regarded as "natives", and foreigners with a permanent residency permit (C permit) form the group of "earlier immigrants" 23

Skill requirements. The skill requirements of a position are codified in a categorical variable of the LSE which I use to classify occupation groups as either "high skill" (high share of workers performing high skill tasks) or "low skill" (low share of workers performing high skill tasks). The skill requirements

\footnotetext{
${ }^{21}$ The exclusion of individuals employed in the public administration is motivated by two observations. Firstly, wages in the public sector are defined and hence likely to be less responsive to labor supply shocks than wages in the private sector. Secondly, the effect of immigration in the public sector is lower simply because recent immigrants are much less likely to work in the public administration than in the private sector (the overall share of recent immigrants in the public sector amounts to 3.2 , the share in the private sector to 7 percent). Robustness checks (the results of which are not included in this essay) show that my results are not driven by the exclusion of employees in the public administration.

${ }^{22}$ Generally, an L permit is issued for foreigners staying in Switzerland for less than a year and a B permit is issued for foreigners staying for longer. According to the SAKE data, which provide information on both the residency permit and the duration of residence, the average residence duration is roughly 5.5 years for holders of a $\mathrm{B}$ or $\mathrm{L}$ permit who are employed and between 18 and 65 years of age.

${ }^{23}$ Foreigners are in a position to be granted a $\mathrm{C}$ permit at the earliest after five years' regular and uninterrupted residence in Switzerland. The SAKE data show that the average residence duration is 21.2 years for holders of a $\mathrm{C}$ permit who are employed and between 18 and 65 years of age.
} 
of a job are categorized in four levels, (i) position that requires a worker to perform highly demanding and most difficult tasks, (ii) position that requires qualified and autonomous work, (iii) position that requires some professional knowledge, (iv) position that features simple and repetitive activities. To easily assess the skill dimension, I define skill levels (i) and (ii) as "high skill tasks" and levels (iii) and (iv) as "low skill tasks".

Occupation-experience groups. I form occupation-experience groups using a worker's actual occupation and his age as a proxy for labor market experience. In terms of age I form three groups of workers: 18-34, 35-49, and 50-65 years. Occupation is categorized based on a list of 23 occupation categories codified in a variable of the LSE. Table 1 characterizes these occupation groups. The table entries are ordered by the share of workers performing "high skill tasks", which - unsurprisingly - is roughly in line with the share of workers with a high level of education and the average real wage earned. For the subsequent analysis, I divide occupations into "high skill occupations" and "low skill occupations" based on this ranking. I draw the line between these two groups after position 8 since there is a drop-off in terms of the share of high skill tasks thereafter, but the exact cut-off is not critical to the results of my analysis. According to this definition, about one quarter of the labor force is employed in high skill occupations and about three quarters are employed in low skill occupations. A distinction between these two categories is necessary since the position of recent immigrants in the resident wage distribution varies greatly between them, which implies differential wage effects ${ }^{24}$

\section{Table 1 about here}

Wages. I calculate the gross hourly wage including bonuses and special payments obtained over the course of the year. It is measured in real Swiss Francs $(\mathrm{CHF}) 25$

\section{$5 \quad$ Main Results}

\subsection{Position of Recent Immigrants in the Wage Distribu- tion of Residents}

The theoretical model outlined above predicts that immigration decreases wages at those parts of the wage distribution where immigrants are overrepresented and increases wages where they are underrepresented. I thus have to assess

\footnotetext{
${ }^{24}$ See Section 5.1 for the differences in the distribution of immigrants.

${ }^{25}$ Wages are deflated using the consumer price index constructed by the BFS; the base year is 2000 .
} 
the position of recent immigrants in the wage distribution of resident workers in order to obtain hypotheses for my regression analysis. It is important to remember that I am only able to obtain unambiguous hypotheses if the position of recent immigrants in the resident wage distribution is roughly the same in all analyzed occupation groups ${ }^{26}$

An analysis of the position of recent immigrants in the wage distribution of natives and earlier immigrants reveals striking differences between two broad categories of occupations. While recent immigrants are overrepresented at the bottom of the wage distribution of natives and earlier immigrants in all low skill occupations, they are overrepresented at the top in all high skill occupations 27 This means that Switzerland on the one hand attracts workers fulfilling the most basic tasks in low skill occupations and on the other hand exceptionally skilled professionals active in high skill occupations. Hence, the requirement that the relative wage distribution of recent immigrants be similar in every single occupation is fulfilled if we run regressions separately for high and for low skill occupations.

Figure 2 illustrates these findings in condensed form. Panels (a) and (b) show the position of recent immigrants in the wage distribution of natives and earlier immigrants, respectively, in high skill occupations, and Panels (c) and (d) the position of recent immigrants in the wage distribution of natives and earlier immigrants, respectively, in low skill occupations. In the left column, that is, Panels (a) and (c), the abscissa indicates the native wage percentile and the ordinate measures probability density. The dashed line illustrates the probability density function of natives. Since 1 percent of natives are located in each native wage percentile, the distribution of natives is horizontal at the level 0.01 . The solid line depicts the Kernel density estimates for the probability density function of recent immigrants ${ }^{28}$ The density of recent immigrants is above average where the solid line is above 0.01 (indicating that more than 1 percent of recent immigrants are located in those wage percentiles). The abscissa in the right column, that is, Panels (b) and (d), indicates the wage percentiles of earlier immigrants and the dashed line the probability density function of earlier immigrants instead of natives, but they are otherwise identical to panels on the left.

\section{Figure 2 about here}

Panel (a) shows that in high skill occupations recent immigrants are un-

\footnotetext{
${ }^{26}$ See Section 3.2 for a detailed explanation.

${ }^{27}$ See Section 4 for the classification of occupations into these two categories.

${ }^{28}$ I use the Gaussian function and STATA automatically calculates the Kernel bandwidth using a rule of thumb.
} 
derrepresented below the 60 th percentile, slightly overrepresented between the 60th and the 80th percentile, and starkly overrepresented above this level. In contrast, recent immigrants are heavily overrepresented in the bottom 15 percentiles in low skill occupations, slightly overrepresented from the 15th to the 40th percentiles, and underrepresented above as is revealed in Panel (c). Panels (b) and (d) show that the position of recent immigrants in the wage distribution of earlier immigrants is nearly the same as in the wage distribution of natives.

Based on these findings, I expect immigration to high skill occupations to benefit the bottom wage percentiles of natives and earlier immigrants and exert pressure on the top percentiles. Conversely, I expect immigration to decrease the bottom and increase the top wage percentiles in low skill occupations. Since the position of recent immigrants in the wage distribution of natives and earlier immigrants is roughly identical, I expect no significant differences in the effect of immigration on wages of natives and earlier immigrants - unless there are significant differences in unobserved characteristics.

\subsection{OLS Estimates}

The findings of the preceding section suggest an analysis of the effects of immigration on the wages of four subgroups of the resident population: natives in high skill occupations, natives in low skill occupations, earlier immigrants in high skill occupations, and earlier immigrants in low skill occupations. I observe a random sample of workers in all even years from 1994 to 2008 in each of these subgroups. I divide all of these samples into occupation-experience groups and calculate the biannual changes in a number of group characteristics to obtain the variables for my regression analysis.

I run a separate regression for every fifth wage percentile to assess the effect of immigration on each percentile. The dependent variable is the biannual change in the respective percentile. I regress these percentile changes on the changes in the share of recent immigrants as well as on control variables for changes in the composition of the labor force (average age, ratio of high to low levels of education, ratio of medium to low levels of education, share of earlier immigrants, and share of cross-border commuters) ${ }^{29}$ Since wages are unlikely to respond to immigration and changes in the composition of the labor force immediately, I use the lagged rather than the contemporaneous changes in these variables as regressors ${ }^{30}$ Additionally, I include dummy variables to control for time fixed effects. Occupation-experience groups are weighted with their sample

\footnotetext{
${ }^{29}$ These regressors are the same in every percentile-regression as they are occupationexperience group-specific.

${ }^{30}$ This conflicts with the use of the time index in 2 However, I use the contemporaneous change in immigrant density in a robustness check.
} 
sizes. The results of this baseline setup are illustrated in Figure 3.

\section{Figure 3 about here}

Panels (a) and (b) in Figure 3 depict the results for natives and earlier immigrants, respectively, in high skill occupations, and Panels (c) and (d) the results for low skill occupations. The abscissa indicates the percentile and the ordinate measures the size of the coefficient. Since I measure the dependent variable in logs and the independent variable in percentage points, a coefficient of 0.01 signifies that an increase in the share of recent immigrants by 1 percentage point leads to a wage increase of about 1 percent. The dashed lines mark the range of the 90 percent confidence interval. Standard errors are robust and clustered on the level of occupation-experience groups in order to account for serial correlation. The patterns for natives and earlier immigrants are very similar. The coefficients for high skill occupations form a downward sloping curve that reaches from 0.015 (natives) and 0.026 (earlier immigrants) to -0.006 and -0.017 , respectively. This is in-line with the prediction of positive coefficients at the bottom and negative coefficients at the top of the wage distribution, which I derived in Section 5.1 based on the position of recent immigrants in the resident wage distribution. While the coefficients at the tails of the distribution are of considerable magnitude, only those at the bottom are statistically significant. However, while the coefficients at the top are not significantly different from zero, they are significantly different from those at the bottom. That is, while there is no clear-cut evidence for negative wage effects of immigration on the top percentiles, there is evidence that they are more negatively affected than the bottom percentiles. The magnitude of the coefficients is significantly larger in the case of earlier immigrants, which implies that the wages of earlier immigrants are more sensitive to immigration than those of natives. The most interesting finding is that the effects along the distribution of wages vary substantially, which leads to average effects close to zero. This emphasizes the fact that the focus of most previous studies on mean wage effects blocks the view on distributional effects of immigration 31

\footnotetext{
${ }^{31}$ I check the robustness of all of these findings in a number of changes to the setup of the percentile regressions. The results are illustrated in table A.1 Column (1) shows the results of regressions that include no control variables and no weights. Column (2) shows the results of regressions including time fixed effects and population controls as in the baseline setup but again no weights. Column (3) presents the results of the baseline setup discussed in the preceding paragraph. In the regressions of column (4), I use a different method to account for the lagged reaction of wages to immigration and changes in the labor force. Specifically, I calculate first differences in all variables from 1994 to 2000 and from 2000 to 2008 instead of calculating them biannually, since it is likely that these time spans are long enough for wage adjustments to take place. These tables also indicate the effects of immigration on mean wages, which is what previous studies usually report. All of these robustness checks confirm the previous findings.
} 
The pattern of the coefficients for low skill occupations seems less sensible. The coefficients are positive at all parts of the wage distribution and of minor magnitude; the confidence intervals are very slim, which suggests a precise estimation. This conflicts with the findings of the preceding section, which suggest negative coefficients at the bottom and positive coefficients at the top of the wage distribution. A possible explanation for these puzzling results is that there is little room for downward adjustment of wages in low skill occupations. Firstly, universally binding collective labor agreements govern labor conditions in many low skill occupations, and these agreements usually include a minimum wage 32 Secondly, the Swiss authorities have taken explicit measures to prevent wage decreases in low skill occupations as a consequence of the FMP [Flankierende Massnahmen] as outlined in Section 22 The absence of evidence for negative wage effects in low skill occupations, which is in-line with the results of Gerfin and Kaiser (2010), is remarkable. It not only conflicts with the common perception of the consequences of immigration but also seems to invalidate a key argument of the adversaries of the liberalization of Swiss immigration policy. However, this does not imply that immigration fails to affect workers in low skill occupations adversely, because there might well be employment rather than wage effects 33

\subsection{Estimates}

The OLS estimates presented in the preceding section have to be interpreted as upper bounds for the true effects of immigration, since the likely endogeneity in the share of recent immigrants gives rise to an upward bias. I present the results of an IV approach in this section that is designed to mitigate the problem of endogeneity. Specifically, I use the change in the share of recent immigrants predicted based on the occupational distribution of foreigners in 1994 to instrument the actual change ${ }^{34}$ I use two stage least squares (2SLS) to estimate the IV coefficients.

The first stage results of my IV approach reveal that my IV can indeed explain a part of the variation in the endogenous regressor but not enough to

\footnotetext{
${ }^{32}$ Universally binding collective labor agreements [allgemeinverbindliche Gesamtarbeitsverträge] for individual occupations (e.g. construction workers, hair dressers, or carpenters) instead of a global minimum wage are a particularity of the Swiss labor market. For a full list of all current agreements see http://www.seco.admin.ch/themen/00385/00420/00430/index.html

331 complete the same robustness checks as for high skill occupations. The results are illustrated in Table A.2 The pattern of coefficients is rather sensitive to changes in the regression setup, but the coefficients are all close to zero. While it thus remains unclear how exactly immigration affects wages in low skill occupations, the absence of any persistent negative pattern suggests that there are not very large adverse wage effects.

${ }^{34}$ For details on the construction of the IV see Section 3.3
} 
rule out the problems associated with weak instruments 35 The coefficient of the IV is positive and statistically significant in all but one specification, but the first stage is rather sensitive to changes in the regression setup and the $F$ statistic is lower than ten in some of the setups ${ }^{36}$ A major reason for the partially weak first stage probably results because nationality is unobserved in my data, and I therefore can only roughly capture the network effects in the occupational choices of newly arriving immigrants. Furthermore, I explain in Section 2 that the FMP has significantly altered the structure of immigration to Switzerland. Thus, a prediction of the occupational choices of immigrants arriving under the new regime based on the choices of immigrants who have arrived under the old regime is likely to be flawed. The results of the second stage must therefore be interpreted cautiously since the bias in the IV estimator may even exceed the bias in the OLS estimator in the case of weak instruments.

The results of the second stage for my preferred specification (biannual changes, time-fixed effects, population controls, and weights) are illustrated in Figure 4. Panels (a) and (b) show the results for natives and earlier immigrants, respectively, in high skill occupations. Contrary to intuition, using an IV approach does not shift the curve of coefficients down but rather rotates it clockwise so that coefficients at the bottom are more positive and coefficients at the top more negative. The downward slope of the curve, which is in-line with the theoretical model, remains intact, which strengthens the evidence found in the preceding section. Standard errors are significantly larger than in the OLS regressions, however, which casts some doubt on the validity of the point estimates. The results for natives and earlier immigrants in low skill occupations are depicted in Panels (c) and (d), respectively. Again, the IV coefficients are overall not substantially lower than the OLS coefficients. As is the case with the OLS coefficients, the IV coefficients do not form an upward sloped curve as the theoretical model predicts. Again, the confidence intervals are wider than in the OLS regressions 37

\section{Figure 4 about here}

In sum, the IV estimation backs up the findings of the preceding section. The coefficients for high skill occupations are positive at the bottom and negative at the top of the wage distribution, while the coefficients for low skill occupations

\footnotetext{
${ }^{35}$ See Table A.3

${ }^{36}$ The econometric literature established the rule of thumb that $F$ has to be larger than ten in order to detect weak instruments (e.g., Bound et al. 1995 or Staiger and Stock. 1997).

${ }^{37}$ I complete the same robustness checks as for the OLS regressions. The results are illustrated in Table A.4 for natives and earlier immigrants in high skill occupations and in Table A.5 for natives and earlier immigrants in low skill occupations. It turns out that the IV estimates for high skill occupations are robust, while the estimates for low skill occupations are again rather sensitive to changes in the regression setup but always close to zero.
} 
are close to zero. There is no evidence for a substantial upward bias in the OLS coefficients, but I cannot entirely rule out this possibility due to the imprecise estimation. Since the results of the IV estimation do not substantially differ from those of the OLS estimation while confidence intervals are much wider, I prefer my OLS results.

\section{A Counterfactual Exercise: How Large Is the Impact of Recent Immigration on Wages in Switzerland?}

The regression analysis in the previous sections revealed the marginal effects of an increase in the share of recent immigrants on the wages of natives and earlier immigrants. In this section, I outline the overall magnitude of the wage effects of immigration to Switzerland during the past decade and a half. I in turn focus on the effects of immigration on the overall wage distribution and the extent of the effects for those population groups, which are most strongly affected by immigration.

\subsection{Overall Effect on Inequality}

Immigration to Switzerland has had two effects on the wage distribution, which I will term the "wage change effect" and the "accounting effect". I indicate the changes in the wage distribution of natives and earlier immigrants caused by the labor supply shock of immigration with "wage change effect", and I refer to the change in the wage distribution of the whole population caused by the inclusion of the recent immigrants with the "accounting effect". In other words, the wage change effect results from competition and complementarity of recent immigrant with workers already living in Switzerland, and the accounting effect results from the addition of the recent immigrants to the labor force. The wage change effect for high skill occupations implies a reduction in inequality since wages decreased at the top and increased at the bottom of the wage distribution. To calculate the extent of this effect, I construct a counterfactual wage distribution for natives and earlier immigrants, that is, I subtract the estimated wage effects of immigration from the actual wages. To calculate the estimated wage effects, I multiply the coefficients obtained in my preferred OLS regressions (see columns (3) for natives and earlier immigrants in Table A.1) by the change in immigrant density from 1994 to 2008 in each occupation group (see Table A.6. The difference between the actual and the counterfactual wage distributions of natives and earlier immigrants represents the wage change effect. My 
analysis does not provide evidence for any significant wage effects for low skill occupations; furthermore the overall share of recent immigrants has remained roughly constant (see Figure 11). I thus assume that the wage change effect for low skill occupations is close to zero. The accounting effect of immigration implies an increase in inequality, since immigrants are overrepresented at the bottom of the wage distribution in low skill occupations and at the top in high skill occupations. In sum, the wage change effect implies a decrease in overall inequality and the accounting effect implies an increase in inequality, so that the total effect is a priori unclear.

An assessment of the three Lorenz curves drawn in Panel (a) of Figure 5 shows which effect dominates. The Lorenz curve drawn in light grey represents the counterfactual for natives and earlier immigrants - that is, the wage distribution I would expect to observe in the absence of immigration. The actual Lorenz curve for natives and earlier immigrants is drawn in dark grey. It lies above the counterfactual curve since the wage change effect implies a reduction in inequality. The Lorenz curve for total population is drawn in black. It lies below the counterfactual curve, which implies that the accounting effect dominates the wage change effect and overall inequality is higher with immigration than it would be without. Since the differences between the three Lorenz curves are almost imperceptible, Panel (b) illustrates the difference between the actual and the counterfactual curve for natives and earlier immigrants (the wage change effect) and the difference between the curve for total population and the counterfactual curve (the total effect) ${ }^{38}$ The Gini coefficients for the total population, natives and earlier immigrants, and the counterfactual for natives and earlier immigrants are $0.263,0.256$, and 0.259 , respectively. That means that the wage change effect amounts to -0.003 , the accounting effect to 0.007 , and the total effect to 0.004 in terms of the Gini coefficient.

\section{Figure 5 about here}

This analysis hence yields two insights: (i) even though recent immigration to Switzerland has reduced inequality among residents (wage change effect), it is likely that total inequality has increased due to the immigrants themselves (accounting effect); (ii) both the wage change and the accounting effect are of minor magnitude from an aggregate perspective, which implies that immigration plays a minor part in the determination of overall wage inequality in Switzerland. There are two important caveats, however. Firstly, the wage change effect is calculated based on the point estimates of my regressions and therefore sub-

\footnotetext{
${ }^{38}$ Reading example: The total effect at 10 percent of the population is about 0.0006 . This implies that the poorest 10 percent of the population dispose of 0.06 percent less of total income than in a hypothetical world without immigration.
} 
ject to some degree of imprecision. And secondly, my whole analysis is restricted to the effects of immigration on gross hourly wage rates. It thus neglects effects of immigration on employment opportunities of residents, on taxes and social security, and on costs of living, which also play important parts in the determination of effective inequality.

\subsection{Effects for Subgroups}

While the effects of immigration seem negligible from an aggregate perspective, they may be of considerable magnitude for subgroups of the population. The sign and magnitude of the expected wage effect for a worker depends on his position in the wage distribution and the extent of immigration to his occupation group. The increase in the share of recent immigrants in high skill occupations has been largest in the occupation group "research and development" (7.5 percentage points from 1994 to 2008; see Table A.6, which implies that the workers in this group are likely to have experienced the largest wage effects. Within the occupation group, the effects are largest for workers at the tails of the wage distribution. Thus, an analysis of the wage effects for the 5th and 95th wage percentile in research and development delivers a picture of the boundaries of the wage effects of recent immigration to high skill occupations. This is done in Table 2, which (for convenience) reports the coefficients obtained in the preferred specification of my OLS and IV regressions (see columns (3) in Tables A.1 and A.4 and the total effect obtained by multiplying these coefficients by the increase in the share of recent immigrants. It is evident that the workers at the tails of the wage distribution experienced substantial wage changes, while immigration only affected mean wages moderately.

\section{Table 2 about here}

I do not expect significant wage effects for low skill occupations since my coefficients are close to zero and the share of recent immigrants in low skill occupations has on average remained about constant (although there are considerable differences between low skill occupation groups).

Again, these calculations have to be taken with a grain of salt since they neglect immigration effects other than on gross hourly wages and since the coefficients are estimated with some degree of imprecision. However, it is safe to claim that immigration has substantial effects for subgroups of the labor force, especially in high skill occupations, despite small effects on average wages and on overall inequality. Specifically, workers who happen to work in occupations that experience large immigrant inflows and who dispose of skills similar to those of immigrants are substantially hurt by immigration, while those whose skill set 
is complementary to immigrant labor enjoy substantial gains from immigration.

\section{Conclusion}

Previous studies on the wage effects of immigration have searched for correlations between immigrant density and the mean wage in subgroups of the population. Since immigration, however, is likely to have different effects on differently skilled residents, Dustmann et al. (2008b) shift the focus from mean wages to the distribution of wages. I follow their lead and add to their insights. I adapt their approach and employ it on a panel of occupation-experience groups (rather than regions) to take the critique of the spatial correlations approach into account. I even go a step further, not only reporting coefficients for different parts of the wage distribution but estimating the effect on overall wage inequality. The subject of my study, Switzerland, is interesting for two reasons. From an international point of view, it provides insights for a country where immigrants are overrepresented not only at the bottom but also at the top of the wage distribution. From a Swiss-oriented point of view it contributes to the current political debate surrounding free movement of persons with the EU and the EFTA.

I find that recent immigrants in Switzerland are overrepresented at the bottom of the wage distribution in low skill occupations and at the top in high skill occupations. Simple economic theory thus suggests that immigration has compressed the wage distribution in high skill occupations and expanded it in low skill occupations. My regression analysis confirms this hypothesis for high skill occupations. This provides strong evidence for the notion that natives whose skill set is similar to that of immigrants lose and natives with a complementary skill set gain from immigration. In low skill occupations, however, I do not find any effects of significant magnitude - although the estimations are rather precise. This finding is likely to be driven by minimum wages anchored in universally binding collective labor agreements and by a set of measures taken by the Swiss authorities to prevent wage decreases in low skill occupations as a consequence of the FMP [Flankierende Massnahmen].

All in all, these "wage change effects" of immigration imply a decrease in overall inequality due to a compression of the wage distribution of natives and earlier immigrants in high skill occupations. However, immigration also has an "accounting effect" on inequality since the newly immigrated workers are also part of the wage distribution. I show that the wage change effect is dominated by the accounting effect of immigration, but also that both effects are rather small in magnitude.

While the overall effects of immigration - both on inequality and on mean 
wages - seem negligible, there are substantial effects for subgroups of the population. Specifically, my OLS estimates imply that wages in research and development - the occupation group that experienced the largest increase in immigrant density - have increased by 11.25 (natives) and 19.5 percent (earlier immigrants), respectively, at the bottom of the wage distribution and decreased by 4.35 (natives) and 12.75 percent (earlier immigrants), respectively, at the top.

All of these findings have to be taken with a grain of salt. Firstly, most estimates are subject to some degree of imprecision - in particular the IV estimates. Secondly, my analysis is not a definitive verdict on the effects of immigration but rather a piece of jigsaw. Namely, it is restricted to the effects of immigration on wages, while immigration has effects on other economic variables as well - above all on employment opportunities of residents, on taxes and social security, and on costs of living. Nevertheless, it is an important contribution to the understanding of the impact of immigration on the host society. Specifically, it confirms the finding by Dustmann et al. (2008b) that pressure is felt at those parts of the wage distribution, where immigrants are overrepresented, in a country with bi-polar immigration. It reveals that while the effects of immigration on the overall wage distribution are small, they are of considerable magnitude at the tails of the wage distribution. Contrary to common notion, negative wage effects are more pronounced at the top of the distribution, while low earners seem to be well protected by wage rigidities and legal measures.

\section{References}

Altonji, Joseph G. and David Card, "The Effects of Immigration on the Labor Market Outcomes of Less-skilled Natives," in John M. Abowd and Richard B. Freeman, eds., Immigration, Trade, and the Labor Market, University of Chicago Press 1991, pp. 201-234.

Avenir Suisse and Daniel Müller-Jentsch, eds, Die neue Zuwanderung: die Schweiz zwischen Brain-gain und Überfremdungsangst, Neue Zürcher Zeitung, Zurich, 2008.

Bartel, Ann P., "Where Do the New U.S. Immigrants Live?," Journal of Labor Economics, 1989, 7 (4), 371-391.

Borjas, George J., "The Labor Demand Curve Is Downward Sloping: Reexamining The Impact Of Immigration On The Labor Market," The Quarterly Journal of Economics, 2003, 118 (4), 1335-1374.

_ , "Native Internal Migration and the Labor Market Impact of Immigration," Journal of Human Resources, 2006, 41 (2), 221-258. 
_ , Richard B. Freeman, and Lawrence F. Katz, "Searching for the Effect of Immigration on the Labor Market," The American Economic Review, 1996, $86(2), 246-251$.

_ , _ , and _ , "How Much Do Immigration and Trade Affect Labor Market Outcomes?," Brookings Papers on Economic Activity, 1997, 1, 1-90.

Bound, John, David A. Jaeger, and Regina M. Baker, "Problems with Instrumental Variables Estimation When the Correlation Between the Instruments and the Endogeneous Explanatory Variable is Weak," Journal of the American Statistical Association, 1995, 90 (430), 443-450.

Card, David, "The Impact of the Mariel Boatlift on the Miami Labor Market," Industrial and Labor Relations Review, 1990, 43 (2), 245-257.

_ , "Immigrant Inflows, Native Outflows, and the Local Labor Market Impacts of Higher Immigration," Journal of Labor Economics, 2001, 19 (1), 22-64.

_ , "Is the New Immigration Really So Bad?," Economic Journal, 2005, 115 (507), F300-F323.

- and John E. DiNardo, "Do Immigrant Inflows Lead to Native Outflows?," American Economic Review, 2000, 90 (2), 360-367.

Dustmann, Christian, Albrecht Glitz, and Tommaso Frattini, "The labour market impact of immigration," Oxford Review of Economic Policy, 2008, 24 (3), 478-495.

_ , _ , and Uta Schönberg, "Referral-based Job Search Networks," 2010. Mimeo.

_ , Tommaso Frattini, and Ian Preston, "The Effect of Immigration along the Distribution of Wages," 2008. CReAM Discussion Paper No. 03/08.

Friedberg, Rachel M., "The Impact of Mass Migration on the Israeli Labor Market," The Quarterly Journal of Economics, 2001, 116 (4), 1373-1408.

Gerfin, Michael and Boris Kaiser, "The Effects of Immigration on Wages: An Application of the Structural Skill-Cell Approach," Swiss Journal of Economics and Statistics, 2010, 146 (4), 709-739.

Grossman, Jean B., "The Substitutability of Natives and Immigrants in Production," The Review of Economics and Statistics, 1982, 64 (4), 596-603.

Hanson, Gordon H. and Matthew J. Slaughter, "Labor-market adjustment in open economies Evidence from US states," Journal of International Economics, 2002, 57 (1), 3-29.

Hunt, Jennifer, "The impact of the 1962 repatriates from Algeria on the French labor market," Industrial and Labor Relations Review, 1992, 45 (3), $556-572$

Ioannides, Yannis M. and Linda Datcher Loury, "Job Information Networks, Neighborhood Effects, and Inequality," Journal of Economic Literature, 2004, 42 (4), 1056-1093. 
Küng, Lorenz, "The Impact of Immigration on Swiss Wages: A Fixed Effects Two Stage Least Squares Analysis," 2005. Mimeo.

LaLonde, Robert J. and Robert H. Topel, "Labor market adjustments to increased immigration," in John M. Abowd and Richard B. Freeman, eds., Immigration, Trade, and the Labor Market, University of Chicago Press 1991, pp. $167-200$.

Lewis, Ethan G., "Local Open Economies within the US: How Do Industries Respond to Immigration," 2004. Federal Reserve Bank of Philadelphia Working Paper No. 04-1.

Lowenstein, Roger, "The Immigration Equation," New York Times July 9, 2006.

Okkerse, Liesbet, "How To Measure Labour Market Effects Of Immigration: A Review," Journal of Economic Surveys, 2008, 22 (1), 1-30.

Ottaviano, Gianmarco I. and Giovanni Peri, "Rethinking the Effects of Immigration on Wages ," 2006. NBER Working Paper No. 12497.

Patel, Krishna and Francis Vella, "Immigrant Networks and Their Implications for Occupational Choice and Wages," 2007. IZA DP No. 3217.

SECO, "Auswirkungen der Personenfreizügigkeit auf den Schweizer Arbeitsmarkt: 6. Bericht des Observatoriums zum Freizügigkeitsabkommen SchweizEU," 2010. Annual report.

Staiger, Douglas and James H. Stock, "Instrumental Variables Regression with Weak Instruments," Econometrica, 1997, 65 (3), 557-586. 
Table 1: Characteristics of Workers in Different Occupations

\begin{tabular}{|c|c|c|c|c|}
\hline \multirow[t]{2}{*}{ Occupation } & \multirow{2}{*}{$\begin{array}{r}\text { High } \\
\text { skill } \\
\quad \%\end{array}$} & $\begin{array}{l}\text { Tertiar } \\
\text { edu- } \\
\text { ca- } \\
\text { tion }\end{array}$ & $\begin{array}{l}\text { TertiaryHourly } \\
\text { edu- wage }\end{array}$ & \multirow{2}{*}{$\begin{array}{r}\text { Labor } \\
\text { force } \\
\text { share } \\
\\
\%\end{array}$} \\
\hline & & $\%$ & $\mathrm{CHF}$ & \\
\hline \multicolumn{5}{|l|}{ High skill occupations } \\
\hline 1. Definition of corporate strategy & 68.5 & 68.4 & 71.34 & 3.0 \\
\hline 2. Research and development & 18.3 & 66.5 & 46.82 & 1.4 \\
\hline 3. Evaluation, consultancy, certification & 15.7 & 44.7 & 50.86 & 3.8 \\
\hline 4. Planning, design, layout & 12.3 & 48.7 & 39.02 & 3.5 \\
\hline 5. Accounting and personnel & 11.9 & 30.4 & 40.93 & 4.6 \\
\hline 6. Analysis, programming, operating & 11.2 & 48.5 & 45.83 & 2.3 \\
\hline 7. Trade in goods & 10.1 & 28.3 & 43.65 & 1.7 \\
\hline 8. Logistics and staff duties & 9.5 & 29.2 & 41.40 & 1.9 \\
\hline \multicolumn{5}{|l|}{ Low skill occupations } \\
\hline 9. Education & 6.9 & 56.9 & 49.26 & 1.7 \\
\hline 10. Culture, information, and recreation & 5.9 & 28.4 & 36.45 & 1.1 \\
\hline 11. Medical, nursing and social functions & 5.3 & 21.6 & 32.57 & 6.6 \\
\hline 12. Other administrative functions & 4.0 & 14.5 & 34.50 & 6.7 \\
\hline 13. Restoration, crafts & 3.9 & 8.2 & 27.43 & 0.2 \\
\hline 14. Security, surveillance & 3.9 & 6.8 & 31.69 & 0.3 \\
\hline 15. Construction & 3.3 & 8.4 & 30.41 & 7.6 \\
\hline 16. Machinery & 2.2 & 7.9 & 31.96 & 6.9 \\
\hline 17. Retail sale of goods and services & 1.8 & 6.3 & 25.92 & 9.6 \\
\hline 18. Manufacturing, processing & 1.8 & 4.9 & 28.14 & 16.3 \\
\hline 19. Secretarial, office work & 1.3 & 9.4 & 32.38 & 5.2 \\
\hline 20. Hotel, catering trade, housework & 1.2 & 4.7 & 22.62 & 7.6 \\
\hline 21. Transport and communications & 1.2 & 3.0 & 28.60 & 4.8 \\
\hline 22. Personal hygiene, dress care & 1.0 & 4.4 & 20.91 & 0.6 \\
\hline 23. Cleaning and public hygiene & 0.2 & 1.3 & 22.46 & 2.6 \\
\hline
\end{tabular}

Notes: The sample includes workers aged 18-65 and employed in the private sector (residents as well as border commuters). All cross-sections from 1994 to 2008 are pooled. Crosssectional weights are adjusted so that every cross-section has the same total weight. The wage refers to gross hourly earnings in real Swiss Francs (base year is 2000). For definitions of skill and education see the main text. Source: $L S E$, BFS. 
Table 2: Estimated Wage Effects of Immigration in Research and Development

\begin{tabular}{|c|c|c|c|c|}
\hline & \multicolumn{2}{|c|}{ OLS } & \multicolumn{2}{|c|}{ IV } \\
\hline & Coefficient & $\begin{array}{r}\text { Total effect } \\
(\%)\end{array}$ & Coefficient & $\begin{array}{r}\text { Total effect } \\
(\%)\end{array}$ \\
\hline \multicolumn{5}{|l|}{ Natives } \\
\hline 5 th percentile & 0.015 & 11.25 & 0.018 & 13.5 \\
\hline Mean & -0.001 & -0.75 & -0.0014 & -1 \\
\hline 95th percentile & -0.0058 & -4.35 & -0.012 & -9 \\
\hline \multicolumn{5}{|l|}{ Earlier immigrants } \\
\hline 5 th percentile & 0.026 & 19.5 & 0.064 & 48 \\
\hline Mean & -0.0016 & -1.2 & -0.0078 & -5.85 \\
\hline 95th percentile & -0.017 & -12.75 & -0.014 & -10.5 \\
\hline
\end{tabular}

Notes: The coefficients are the results from the preferred specification of my OLS and IV regressions (columns (3) in Tables A.1 and A.4. The total effects are calculated by multiplying the respective coefficient by the increase of 7.5 percentage points in the share of recent immigrants in research and development, which is the largest increase for any occupation group. Source: LSE, BFS. 
Figure 1: Education Levels of Recent Immigrants in Switzerland

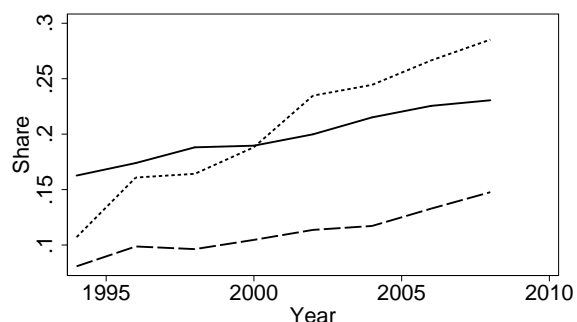

........ Recent immigrants - Natives

(a) Share with Tertiary Education

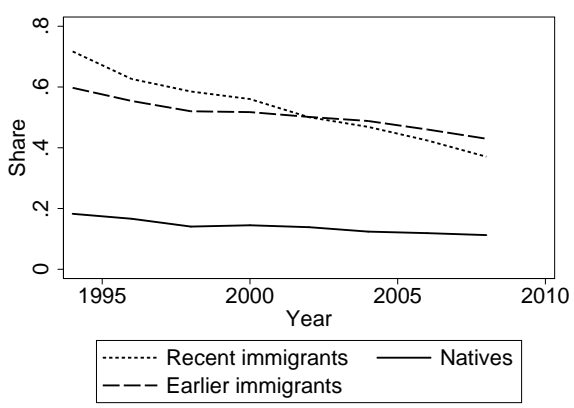

(b) Share with Mandatory Education or Less

Notes: The sample includes all workers aged 18-65 and employed in the private sector. "High educated" refers to workers with a tertiary education, "low educated" to workers who have completed no more than the mandatory part of education. "Natives" are Swiss citizens, "earlier immigrants" workers with a permanent residency permit, "recent immigrants" individuals with a temporary residency permit. For details on these definitions Section 4 Source: LSE, BFS. 
Figure 2: Position of Recent Immigrants in the Wage Distribution of Natives and Earlier Immigrants

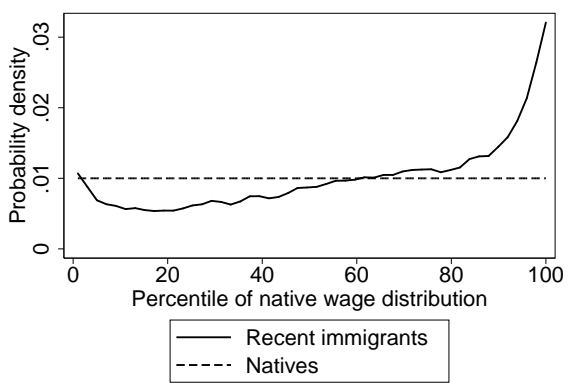

(a) Natives, High Skill Occupations

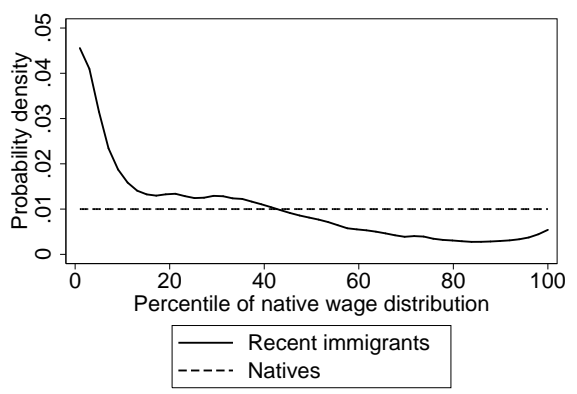

(c) Natives, Low Skill Occupations

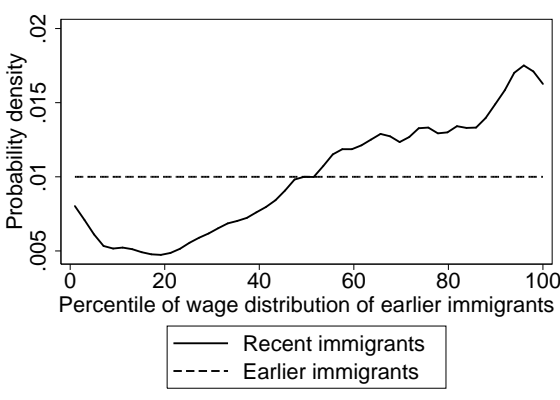

(b) Earlier Immigrants, High Skill Occupations

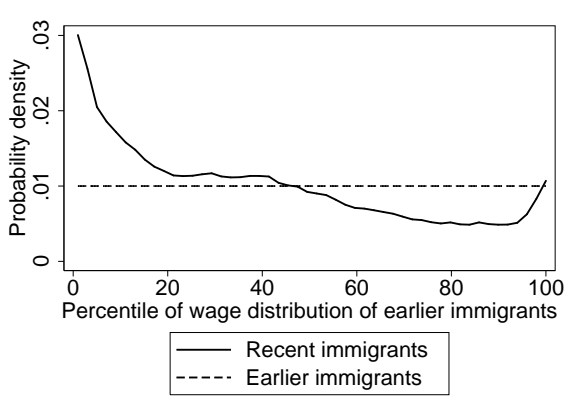

(d) Earlier Immigrants, Low Skill Occupations

Notes: The abscissa indicates the percentile of the wage distribution of natives or earlier immigrants, the ordinate measures probability density. The distribution of natives and earlier immigrants across wage percentiles of natives and earlier immigrants, respectively, is illustrated by the dashed line. The Kernel density estimates of the distribution of recent immigrants are illustrated by the solid line. Source: LSE, BFS. 
Figure 3: OLS Estimates for the Effect of Immigration on the Wages of Natives and Earlier Immigrants

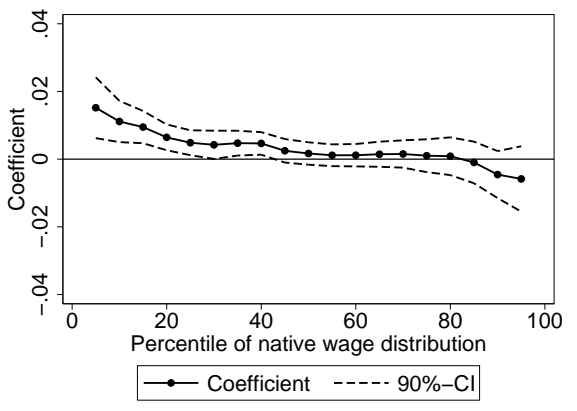

(a) Natives, High Skill Occupations

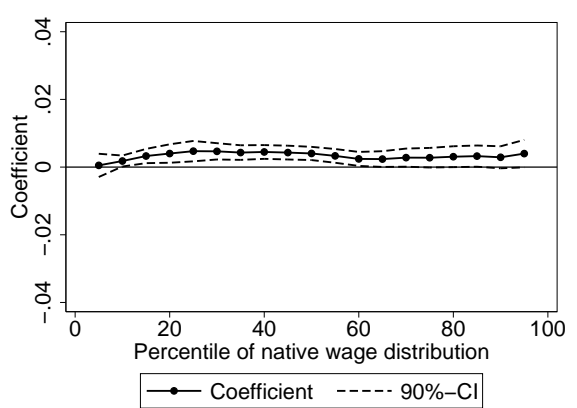

(c) Natives, Low Skill Occupations

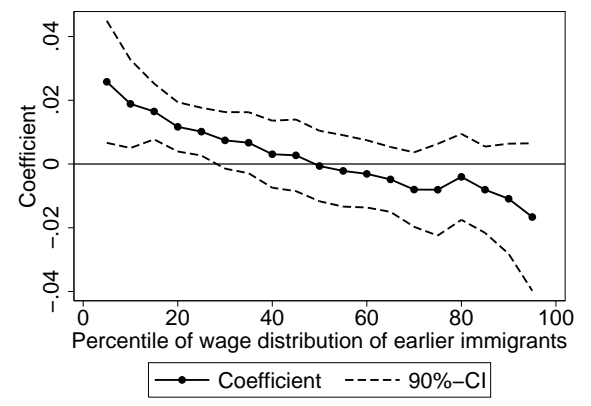

(b) Earlier Immigrants, High Skill Occupations

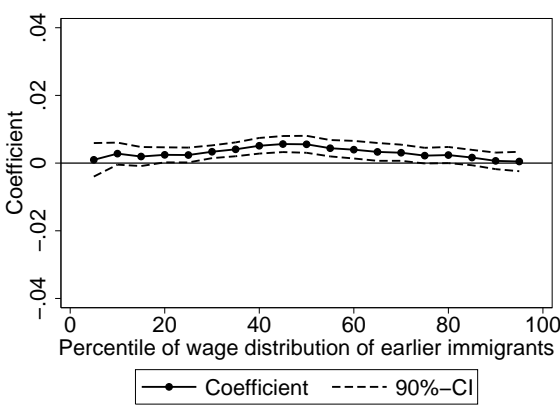

(d) Earlier Immigrants, Low Skill Occupations

Notes: The figure illustrates the OLS regression results of my preferred specification. The abscissa indicates the percentile of the wage distribution of natives or earlier immigrants, the ordinate measures the respective coefficient. Dependent variable is the change in the $\log$ of wage percentiles. Independent variable is the lag of the change in the share of recent immigrants. Time fixed effects and population controls are included. The regressions include all cross-sections from 1994-2008. Occupation-experience groups are weighted by numbers of observations. Standard errors are robust and clustered on the level of occupation-experience groups. Source: LSE, BFS. 
Figure 4: IV Estimates for the Effect of Immigration on the Wages of Natives and Earlier Immigrants

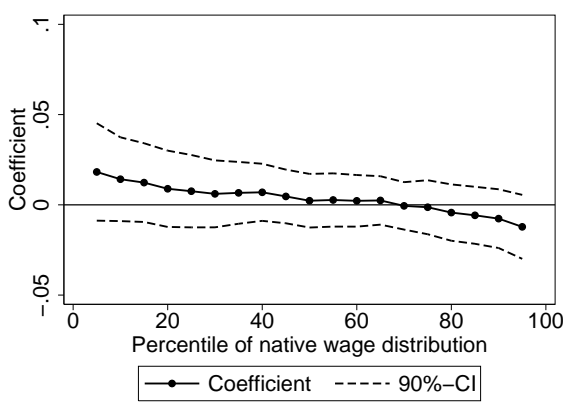

(a) Natives, High Skill Occupations

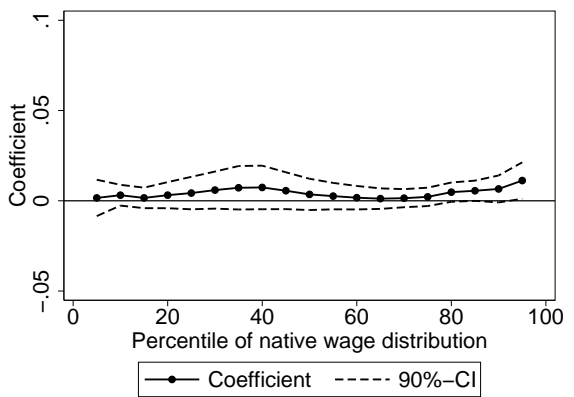

(c) Natives, Low Skill Occupations

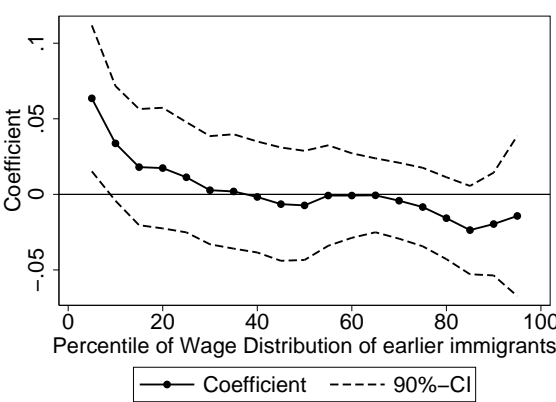

(b) Earlier Immigrants, High Skill Occupations

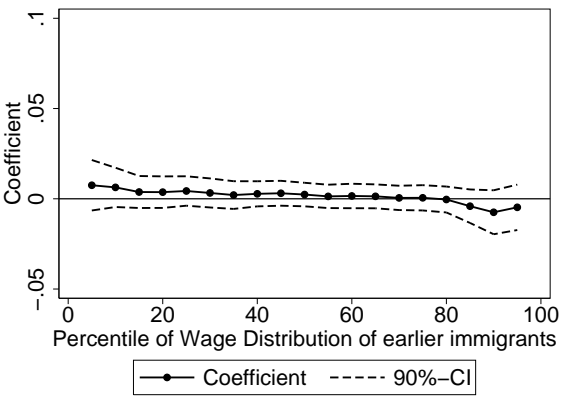

(d) Earlier Immigrants, Low Skill Occupations

Notes: The figure illustrates the IV regression results of my preferred specification. The abscissa indicates the percentile of the wage distribution of natives or earlier immigrants, the ordinate measures the respective coefficient. Dependent variable is the change in the log of wage percentiles. Independent variable is the lag of the change in the share of recent immigrants. IV is the change in the share of recent immigrants as predicted based on the distribution of immigrants across occupations as of 1994. Time fixed effects and population controls are included. The regressions include all cross-sections from 1994-2008. Occupationexperience groups are weighted by numbers of observations. Standard errors are robust and clustered on the level of occupation-experience groups. Source: LSE, BFS. 
Figure 5: Effects of Immigration on Overall Inequality

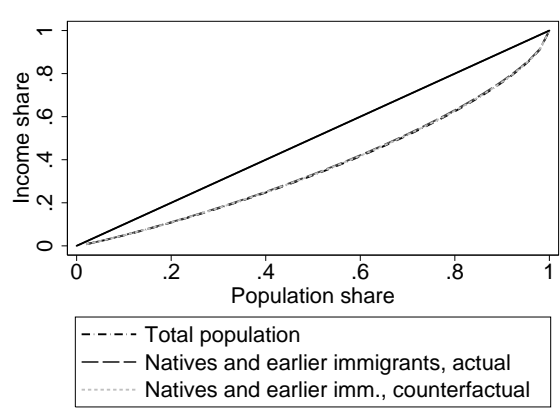

(a) Lorenz Curves

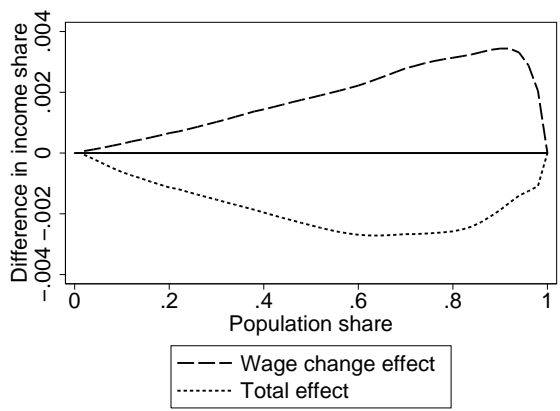

(b) Differences Between Lorenz Curves

Notes: Panel (a) depicts the Lorenz curves for the actual Swiss labor force (total pouplation), the labor force without recent immigrants (natives and earlier immigrants, actual), and the labor force without recent immigrants and without the estimated wage effect of recent immmigration (natives and earlier immigrants, counterfacutal). Panel (b) illustrates the differences between these Lorenz curves. The difference between the actual and the counterfactual curve for natives and earlier immigrants is termed the "economic effect". The difference between the curve for total population and the counterfactual curve for natives and earlier immigrants is termed the "total effect". Source: LSE, BFS. 
A Additional Tables 


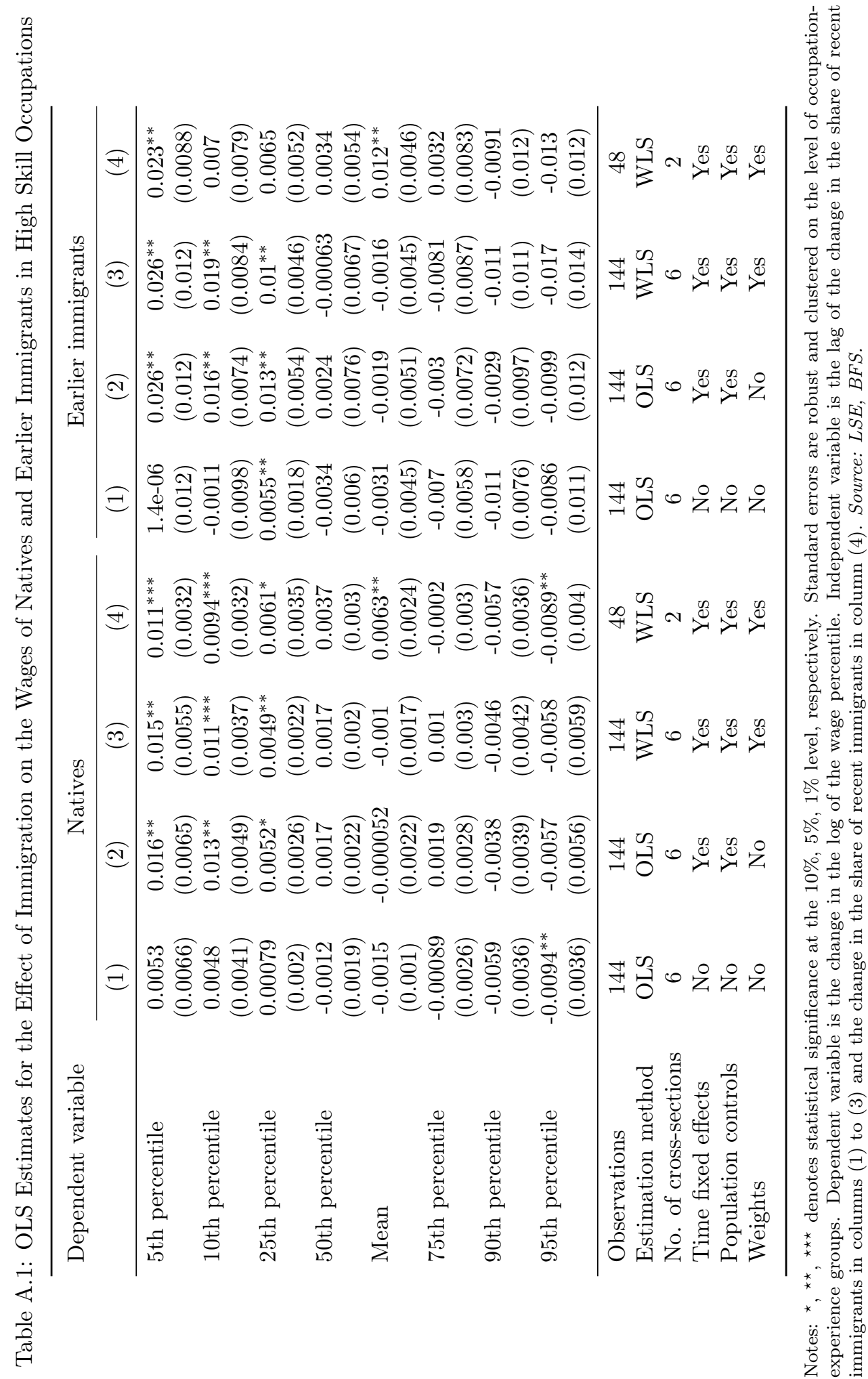




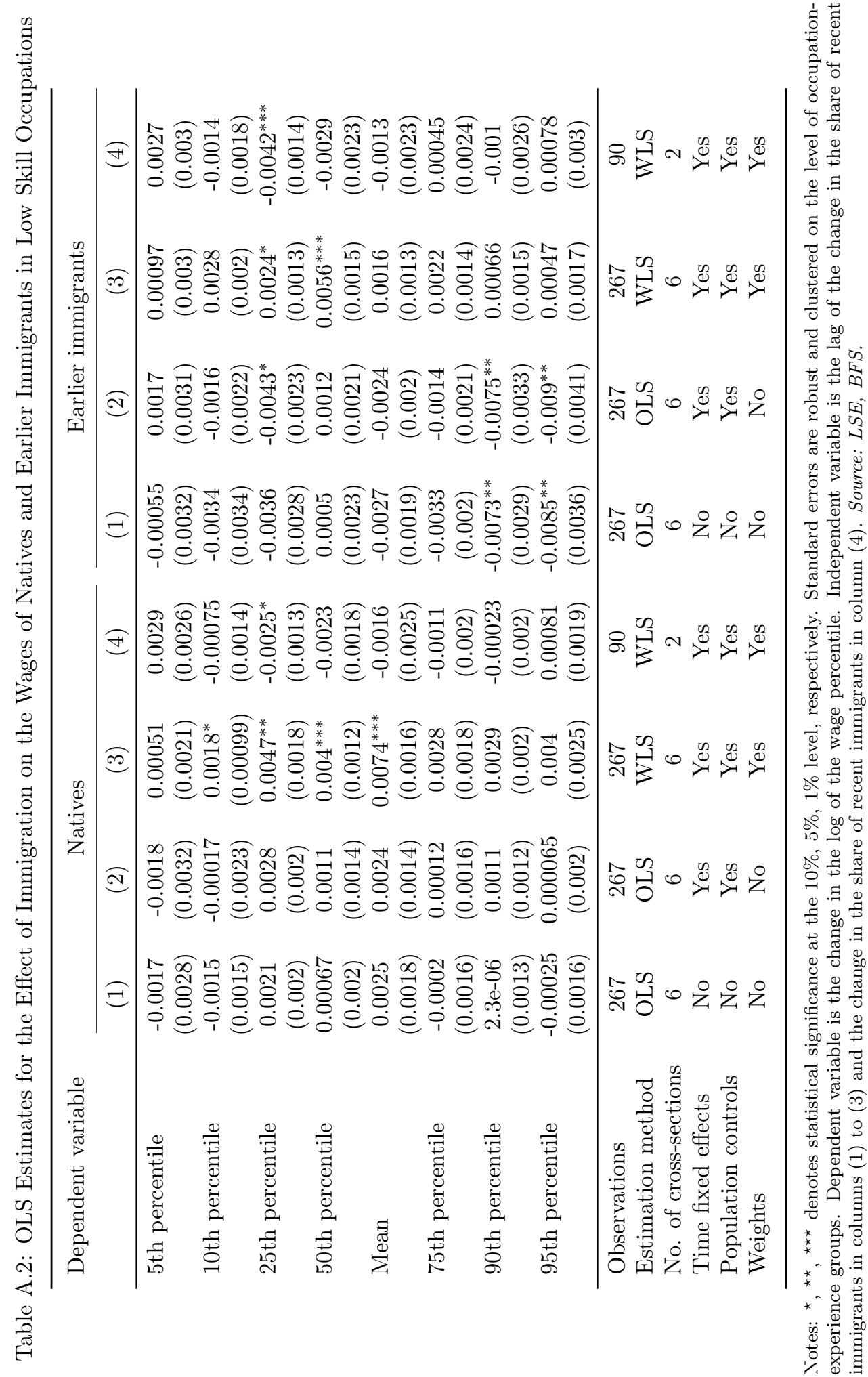




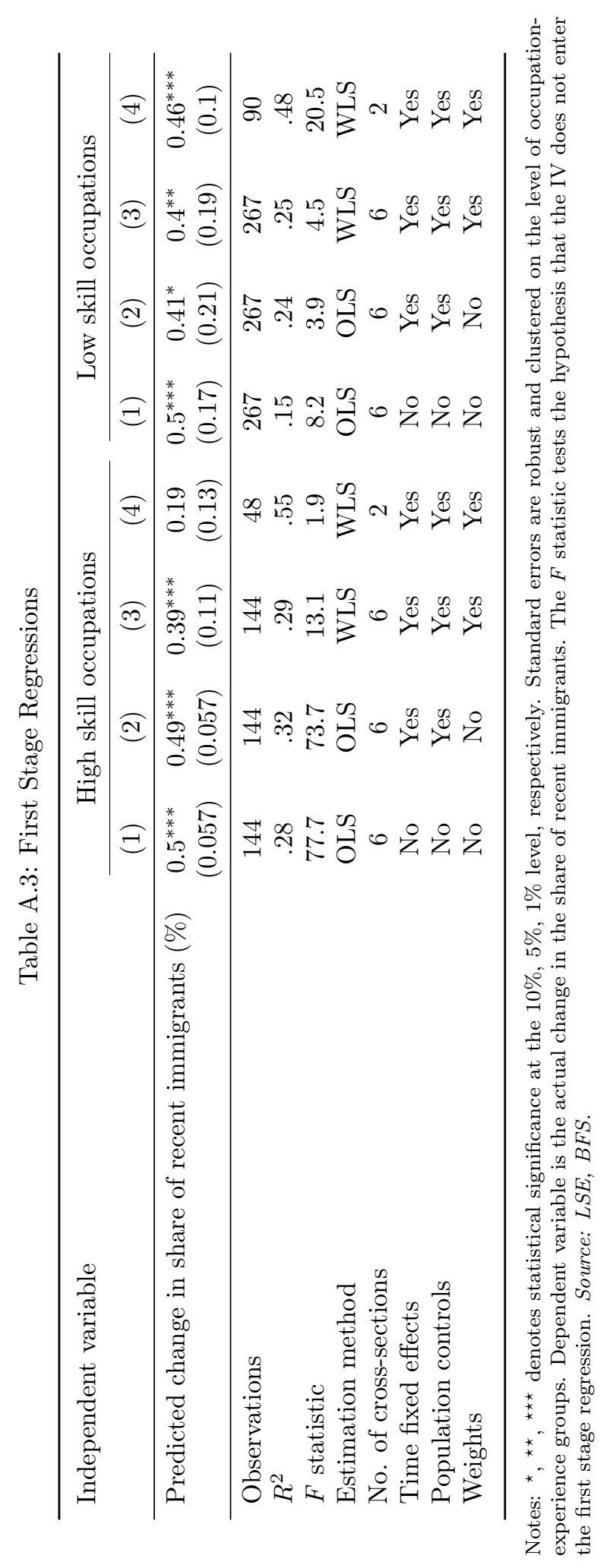




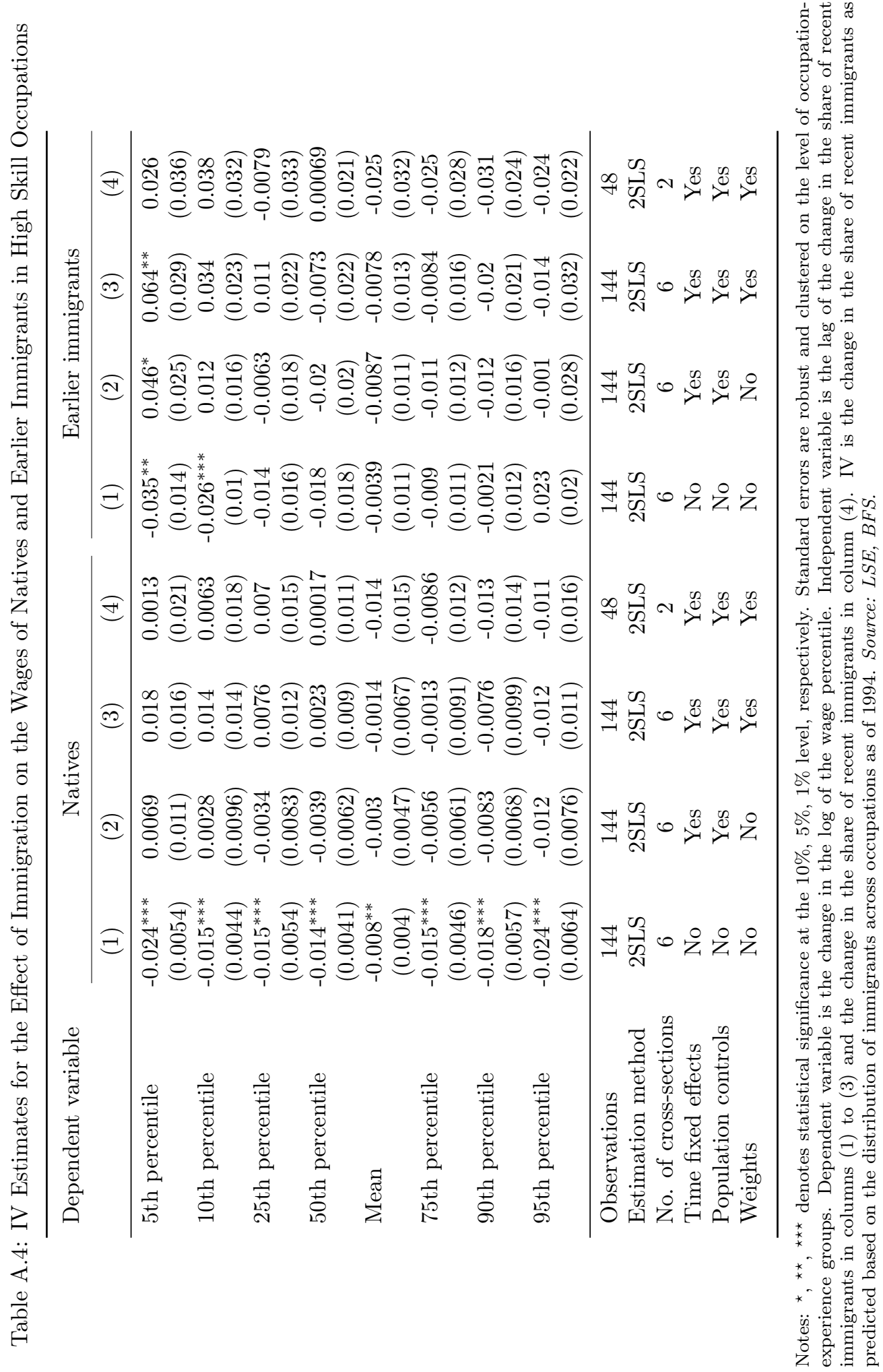




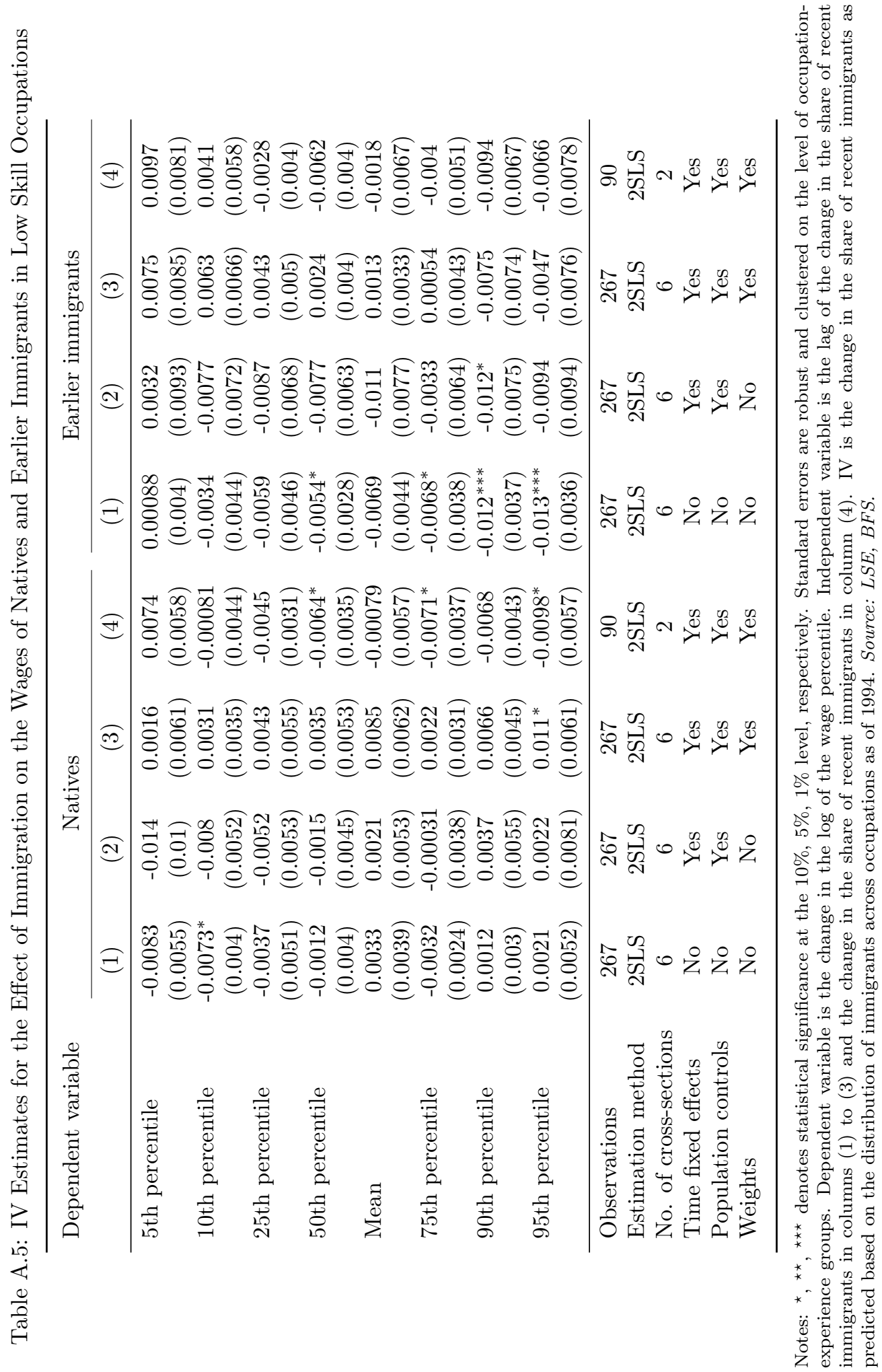


Table A.6: Changes in the Density of Recent Immigrants, 1994-2008

\begin{tabular}{lr}
\hline Occupation & $\begin{array}{r}\text { Change in density of } \\
\text { recent immigrants } \\
(\mathrm{pp})\end{array}$ \\
\hline High skill occupations & \\
Research and development & 7.5 \\
Evaluation, consultancy, certification & 5.6 \\
Analysis, programming, operating & 4.7 \\
Planning, design, layout & 4.4 \\
Trade in goods & 3.9 \\
Logistics and staff duties & 3.6 \\
Accounting and personnel & 3.1 \\
Definition of corporate strategy & 2.3 \\
Low skill occupations & \\
Cleaning and public hygiene & 6.9 \\
Personal hygiene, dress care & 3.6 \\
Other administrative functions & 3.4 \\
Secretarial, office work & 3.0 \\
Culture, information, and recreation & 2.8 \\
Security, surveillance & 2.7 \\
Education & 2.6 \\
Retail sale of goods and services & 1.7 \\
Transport and communications & 1.2 \\
Manufacturing, processing & 1.0 \\
Machinery & 0.1 \\
Medical, nursing and social functions & -0.5 \\
Hotel, catering trade, housework & -4.9 \\
Construction & -6.2 \\
Restoration, crafts & -8.5 \\
\hline
\end{tabular}

Notes: The sample includes workers aged 18-65 and employed in the private sector (residents as well as border commuters). Source: LSE, BFS. 